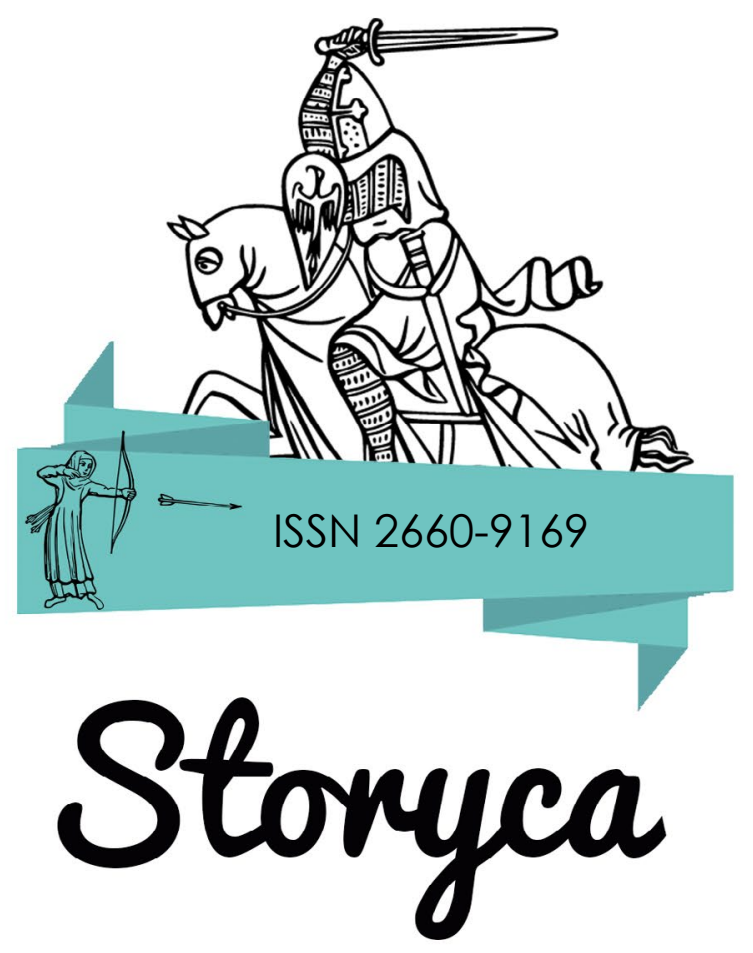

\title{
Re-framing the Crusades: The Representation of Space, Landscape and Architecture in the Comics Series Croisade
}

\author{
SANDRA GORGIEVSKI
}

University of Toulon

By nature the chivalry myth of the crusades allows for the fertile representation of space with the appearance of varied mirabilia. In both medieval and contemporary culture, defamiliarization in space frames the imagined relationship with the other in fantasized views of the East. This paper' addresses ways the creative imagination functions in the first cycle «Hierus Halem» of the Belgian comics series Croisade by Jean Dufaux and Philippe Xavier (vol. I-IV, 20092014). The Third Crusade (1189-1192) following Saladin's 1187 conquest of Jerusalem provides a tentative historical reference point, as well as mythical patterns of the rise and fall of ambitious individuals, the splitting of political alliances, deadly religious feuds, divided loyalties and the disregard of family ties. As a subject, the romantic

1. This paper was presented at the MAMO International Conference (The Middle Ages in the Modern World) in Rome, 2124/11/2018; abstracts published in Middle Ages without borders: a conversation on medievalism : Medioevo senza frontiere : una conversazione sul medievalismo / Moyen Âge sans frontières: conversation sur le médiévalisme, Tommaso di Carpegna, Falconieri, Pierre Savy and Lila Yawn (dirs.), Rome : Publications de l'École française de Rome, 2021, <http://books.openedition. org/efr/18397>. 
idea of the crusades provides fascinating authority figures and a wide range of abstract moral choices, including such issues as personal sacrifice, social responsibility and the need for the unity of a kingdom. It can be seen as a cultural heritage from the $19^{\text {th }} \mathrm{C}$. Western world, in which, according to Adam Knobler,

The Middle Ages recalled a time of moral absolutes, romantic heroism, and noble deeds - a far cry from the Gatling guns and artillery that marked the modern artillery experience [...] The use of crusading images corresponded to the need on the part of traditionalist forces to forge cultural symbols of their own (Knobler, 2006: 307-308).
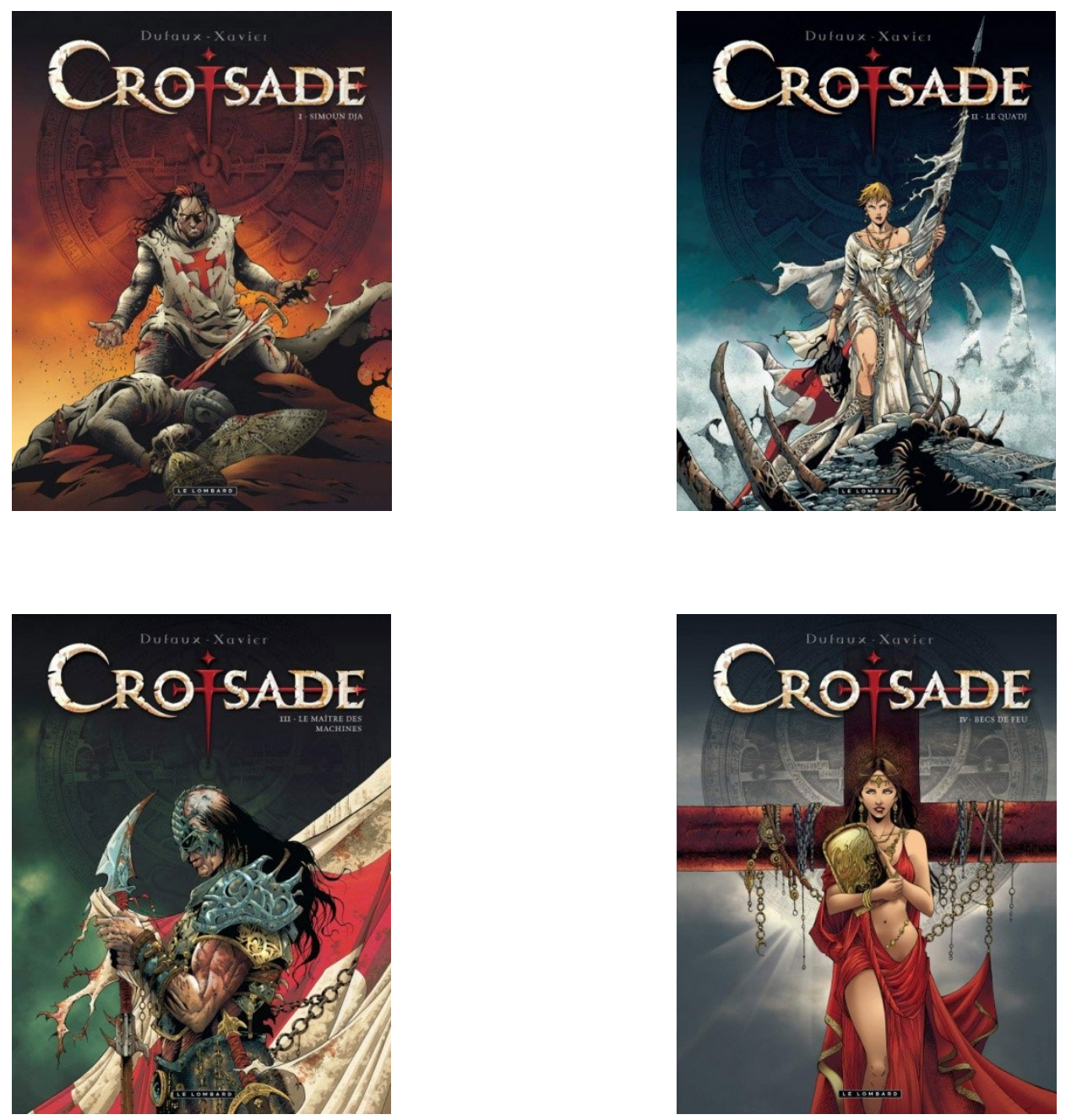

Croisade (vol. I-IV), Dufaux-Xavier, (C) Le Lombard

In volume I Simoun Dja, Jerusalem is in the hands of Sultan Ab'dul Razim and the Christians have raised an army to take it back, led by Grégoire d'Arcos and the Duke of Taranto. Only Gauthier de Flandres and his sister-in-law Syria d' Arcos are opposed to an attack they deem premature. In volume II Le Qua'dj, the Crusaders' army has been destroyed. Gauthier has joined the Jews of Samaria. Christians and Muslims alike are torn by internal conflicts and temptations of the demon Quad'dj. In volume III Le maître des machines, Gauthier fights with his Jewish ally against the apocalyptic "AA» underground monster while the Master of the Machines plots to defeat the Duke of Taranto. In volume IV Becs 
de feu, with the Master of the Machines as their new leader, the Crusaders assault Jerusalem. The sultan must choose between his love for the Christian princess Syria and his faith.

For Dufaux and Xavier, designing animaginary space has entailed representing a highly personalized period, calling on the imagery of contemporary, postmodern heroic fantasy. Far from reducing space and architecture through pseudo-historical re-creation of the past, they foster a self-reflexive vision of competing universes, from the Celtic to the ancient Roman, and from the Moorish to the Gothic. The cultural relativism of our contemporary era seems more relevant than any attempt at faithfully historicizing the otherwise fictional plot. Indeed, according to historian Dalibor Vesely, the fragmented state of today's society and the splintered identities of our technology-dominated contemporary era represent a fascinating challenge for space designers:

Once the continuity of shared meaning has been broken into fragments of understanding, it is unrealistic to expect ambitious abstract structures and their implied meaning to be understood as their authors intended [...]. We may feel, quite rightly, that there is a gap in communication not only between people or people and buildings, but between different areas of culture itself (Vesely, 2004: 13).

Beyond the physiognomy of buildings, representing space concerns our relation with architecture and space. The result is a complex framework of references, shifting the traditional medieval cosmological conception of space as a highly ordered, understandable universe with an easily identifiable symbolism recognized and shared by all, to modern fragmentation. These historical conceptions are representative of the $21^{\text {st }} \mathrm{C}$. malaise:

\begin{abstract}
It is a source of an unprecedented freedom to produce new works but also of an overwhelming relativism, loss of meaning, and narrowing range of common references - and, as a result, of a general cultural malaise [...] On the one hand, it is assumed that true creative architecture should be free from historical and other unnecessary references in order to be as original and unique as possible. And yet, on the other hand, it is expected that the result should be universally understood, appreciated, and accepted (Vesely, 2004: 25)
\end{abstract}

The medieval, sanctified, stable ensemble of places formed a space of «emplacement» where everything was, as Michel Foucault says, «localized». Starting with Galileo's constitution of an infinitely open space, from the $19^{\text {th }}$ c. onward our epoch has increasingly become that of ujuxtaposition» and "dispersion», a world of "extension» in a somewhat de-sanctified space, thus creating heterogeneity and anxiety:

The anxiety of our era has to do fundamentally with space, no doubt a great deal more than with time [...] The space in which we live, which draws us out of ourselves, in which the erosion of our lives, our time and 
our history occurs, the space that claws and gnaws at us, is also in itself, a heterogeneous space (Foucault, 1984: 1-3).

These remarks will examine how these comic books exploit the visual evidence of space as, among other things, emblematic natural sites like the desert, and architectural sites like the sacred city of Jerusalem, burial sites, the sultan's oriental palace and the Crusaders' fortress, while assessing the changing representation of space from the medieval era to the present, that structures the evolving, mutual perceptions between the East and the West.

\section{Natural Space}

\section{The Desert as Spiritual Landscape}

The oriental desert as portrayed by Dufaux and Xavier reactivates the category of the «désert-forêt» in medieval romances, characterized by French historian Jacques Legoff as a site of ordeal, confrontation with adversity and the self and, drawing on Biblical representations, temptation by the devil (Le Goff, 1985: 59-75). Indeed, the desert is a typological landscape linked to the geographical setting of the Egyptian desert, a term that has become loaded during early Christendom with associations of retreat and spiritual growth, even becoming a literary artefact and the Christian monastic ideal of desert spirituality, according to Claudia Rapp (2006: 107-108): "Those who retreated to a "typological" or "functional" desert usually did so close to home, and for a limited period of time. For them the 'desert' experience was a transitional stage [...] a rite of passagen (Rapp, 2006: 112).

In the comics Croisade, the oriental desert where Gauthier finds refuge corresponds to such a cultural category. Beyond the overt Christian reference, one can also relate it to the first type of uheterotopias» identified by Michel Foucault. Unlike unreal utopias, heterotopias are real places that function like counter-sites, or effectively enacted utopia. The first category concerns privileged or sacred places without geographical marks where humans undergo a major crisis:

In the so-called primitive societies, there is a certain form of heterotopia that I would call crisis heterotopias, i.e. there are privileged or sacred or forbidden places, reserved for individuals who are, in relation to society and to the human environment in which they live, in a state of crisis (Foucault, 1984: 4).

In the comics series for example, self-exiled Gautier de Flandres embodies such an errant knight in the wilderness facing his doom (vol. I: 32). His caption thoughts read like pseudo quotations from the Bible: «Et souviens-toi: chacun 
se retrouvera seul devant l'épreuve de vérité» («Remember! Everyone will be alone in front of the test for truth»). Rejected by the Crusaders because of his diverging military strategy, he asks the Jewish tribes for help and discovers religious relativism (vol. I: 46-47). The desert is furthermore associated with dangerous natural forces, like the threatening winds Simoun dja that help the Muslims defeat the Crusaders. In the desert, all characters are threatened by an evil force called the Qua'dj.

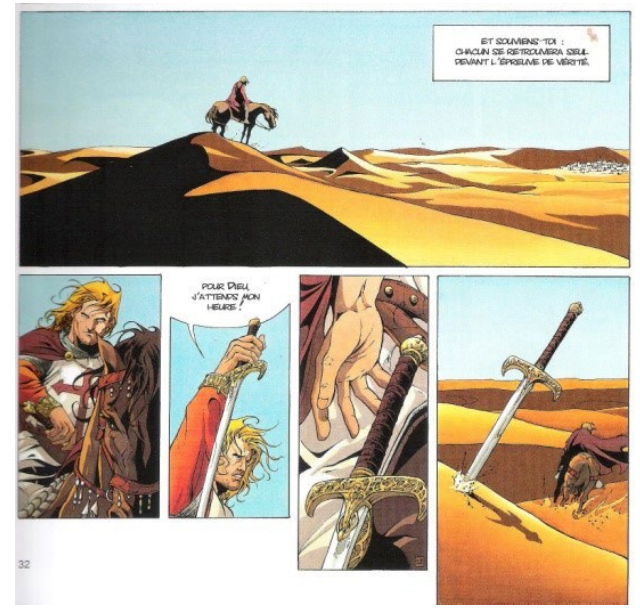

Croisade (vol. I: 32), Dufaux-Xavier, @ Le Lombard

Wells are specific places of temptation and illusion, just as wells, rivers and fountains are in medieval romances. Gauthier de Flandres faces hallucination ${ }^{2}$ by an empty well (vol. II: 5), only to refuse the fresh water offered by a demon that enigmatically disappears into the distance, as if gradually dissolving into the sandy dunes at flamboyant sunset. Four horizontal panels bring solemnity to the event (vol. II: 9), showing the desert as essentially placeless, and the «nowhere» of crisis heterotopias. Gauthier ultimately resists temptation there, refusing to take part in the siege of Jerusalem, allowing the sultan to keep the city, establish a peace treaty with the Christians, allowing them access to pilgrimage (vol. IV: 45-46).

A small mosque in the middle of the desert appears as a sacred space for spiritual encounter, even to Christian characters (vol. I: 5). Significantly, this architecture never fully appears as a whole, and its structure is visually fragmented into various panels: its outdoor facade with

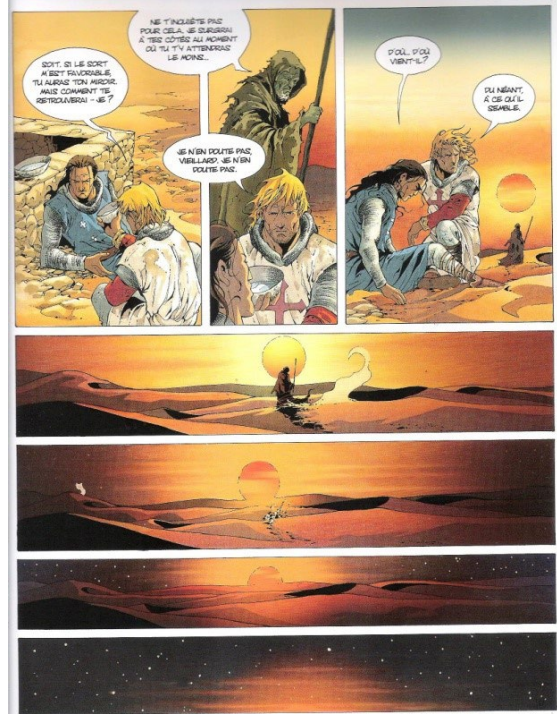

Croisade (vol. II: 9) Dufaux-Xavier, @ Le Lombard

2. See Merleau-Ponty's description of hallucination: «L'illusion de voir est donc beaucoup moins la présentation d'un objet illusoire que le déploiement et comme l'affolement d'une puissance visuelle désormais sans contrepartie sensoriellen (the illusion of seeing is therefore much less the presentation of an illusionary object than the spread and so to speak running wild of a visual power which has lost any sensory counterpart) (1945: 409, quoted by Vesely, 2004: 38-39). 
Moorish door, its internal, circular hall of highly decorated walls with Arabic calligraphy and geometrical patterns and, partially seen from a distance, its high square building surrounded with Roman vestiges. The lamp illuminating it functions less as Orientalist artefact straight from Aladdin's tales than as more traditional suggestion of spiritual enlightenment (vol. I: 9).

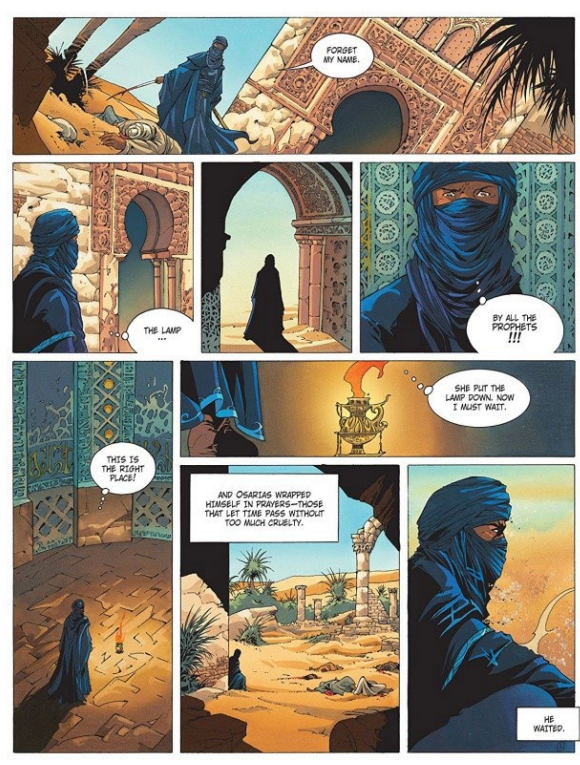

Croisade (vol. I: 5)

Dufaux-Xavier, ( Le Lombard

Syria, the female heroic counterpart to Gauthier, meets in the mosque a beautiful, awe-inspiring, supernatural female creature called the Light of the Martyrs, whose role is to put Christians to the test. The Light of the Martyrs gives Syria a magical object that everybody yearns to possess - a mirror (vol. I: 11). The mirror is what Michel Foucault defines as a Utopian «placeless placen, a sort of shadow that gives one's own visibility to oneself. From this virtual space on the other side of the glass, subjects can reconstitute themselves there where they are: «l see myself as there where I am not, in an unreal, virtual space that opens up behind the surface [...] from the standpoint of the mirror I discover my absence from the place where I am since I see myself over theren (Foucault, 1984: 4).

In the series, the mirror indeed reflects the equivalent of nothing, a mere shadow or a demonic face if the bearer is not pure. Robbed from Syria, reclaimed by a demon (vol. II), it circulates between all the spaces that it thus unites, from the multifarious natural sites to the city of Jerusalem, before its keeping in the Crusaders' castle. It is the magic key revealing the truth about oneself or others, especially demonic presence. Everybody seems to be contaminated, including the ambitious Robert, Duke of Taranto (vol. I: 42; vol. II: 20, 43), the greedy Primate of Venice (vol. II: 32) and the treacherous Eleonore d'Arcos (vol. IV: 12). Robert wants to break the mirror, but the shattered glass recomposes itself each time while his own self dissolves into nothingness (vol. III: 24-25). Its pure essence is finally regained by the spiritual reflection of the Light of the Martyrs (vol. IV: 31 ).
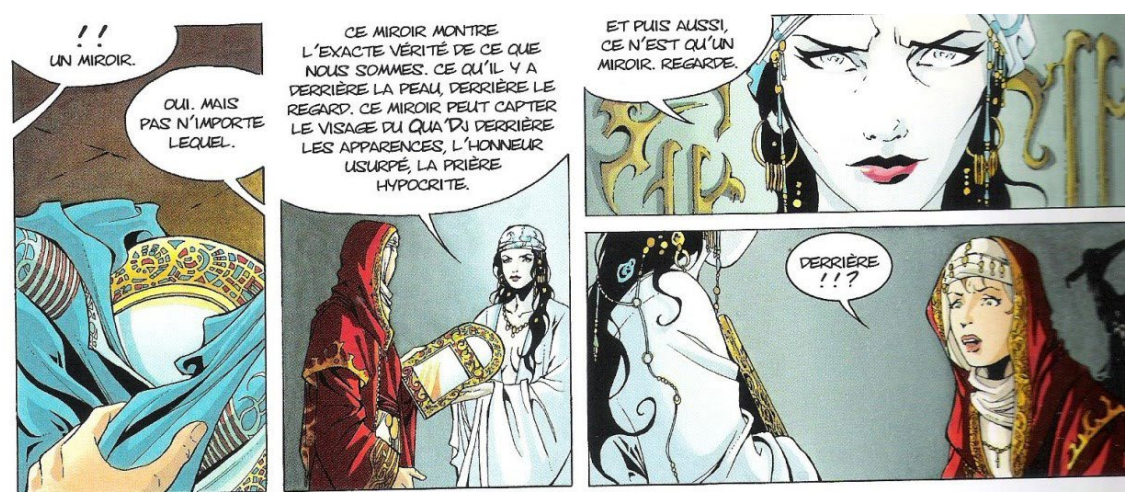

Croisade (vol. I: 11), Dufaux-Xavier, (C) Le Lombard 


\section{The Desert as Battle Site}

The Crusaders' camp displays the precarious architecture of tents adorned with blazons and the Red Cross of the Knights Templar - a historical order founded in 1119 and active until about 1312. They are plotting to regain the shrine of Christ in the Holy Sepulchre of Jerusalem under the guidance of King Grégoire d'Arcos and his Catholic bishop (vol. I: 32). A double-page panel features the Crusaders' tents silhovetted against the sky at night (vol. I: 22-23). It is a dangerous place where evil spirits called djinns lurk to rob warriors of their wives (vol. III: 37).

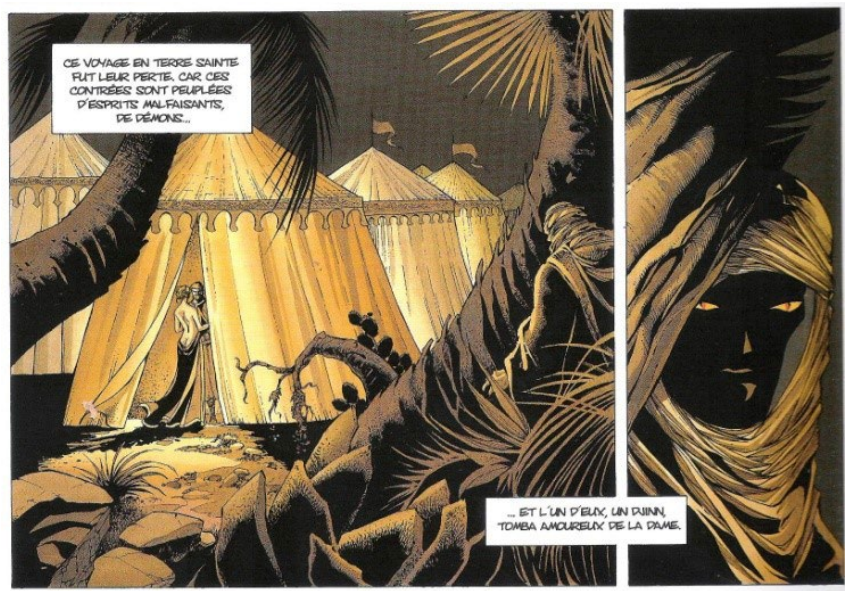

Croisade (vol. III: 37) Dufaux-Xavier, @ Le Lombard

Crusaders regularly confront Muslim soldiers in epic battles which designers highlight thanks to careful framing: a double-page enlarges warrior figures in a battle taking place in a mysterious, unmapped territory called Riozs Azejura (vol. I: 34-35). Led by Sultan Ab'dul Razim, the Muslims rage against the Crusaders then lay siege to their fortress in gory fantasy battles designed in a fold-out of a four-page spread (vol. II: 36-39).
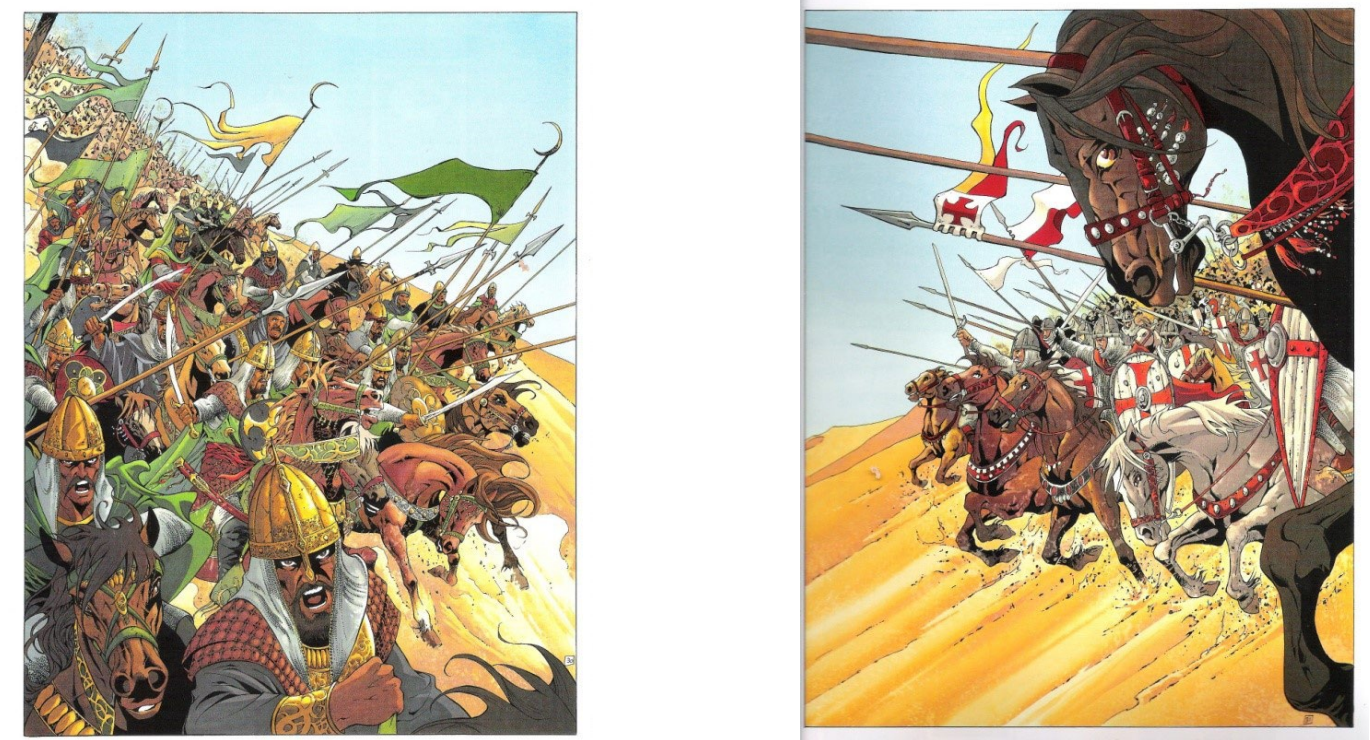

Croisade (vol. I: 34-35) Dufaux-Xavier, @ Le Lombard 
The desert often appears in stylized panels with blood-reddened, apocalyptic, post-battle shadows (vol. II: 28). Religious fanatics attack Gauthier and his Jewish friend Nakash in a narrow rocky pass visually recalling the film tradition of the western, with its stagecoaches attacked in gorges by Indians or on steep cliffs (II: 10-13).

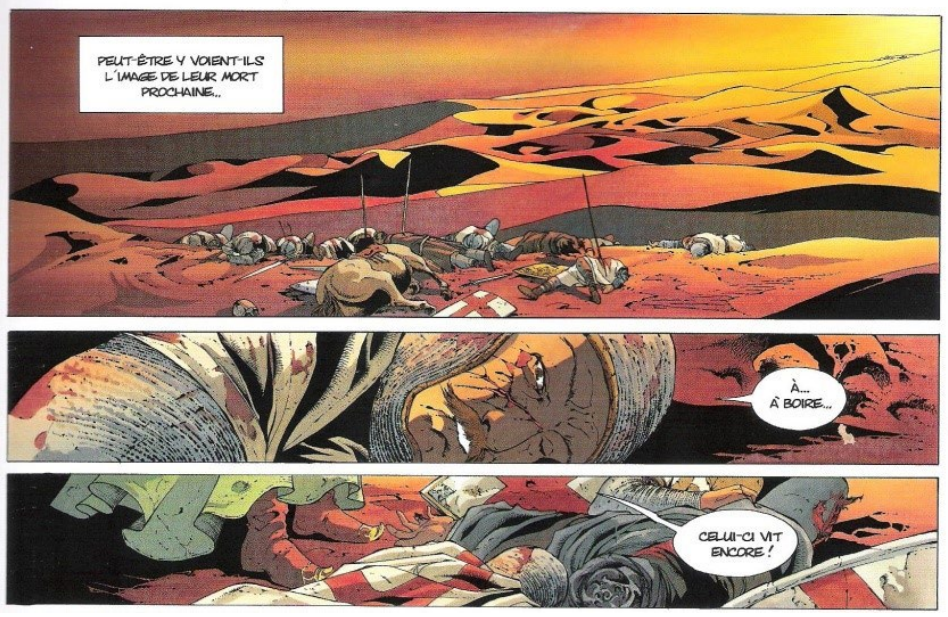

Croisade (vol. II: 28) Dufaux-Xavier, (C) Le Lombard

\section{The Exotic Desert: Cross-fertilization between $19^{\text {th }} \mathrm{C}$. Orientalism and Fantasy}

In addition to the above, the oasis and the palm grove in Croisades are not realistic geographical markers, but rather signifiers of a heterotopic space -an «elsewhere» redolent of Orientalist painting. Edward Saïd's definition of Orientalism as the projection of $19^{\text {th }} \mathrm{C}$. Western fantasized views is relevant here. For example, the caravan crossing the desert is the site where Syria is abducted by a Muslim tribe and the mirror is stolen (vol. II: 22). Nearly dying of thirst, she is abducted in the tantalizing oriental desert (vol. II: 27).

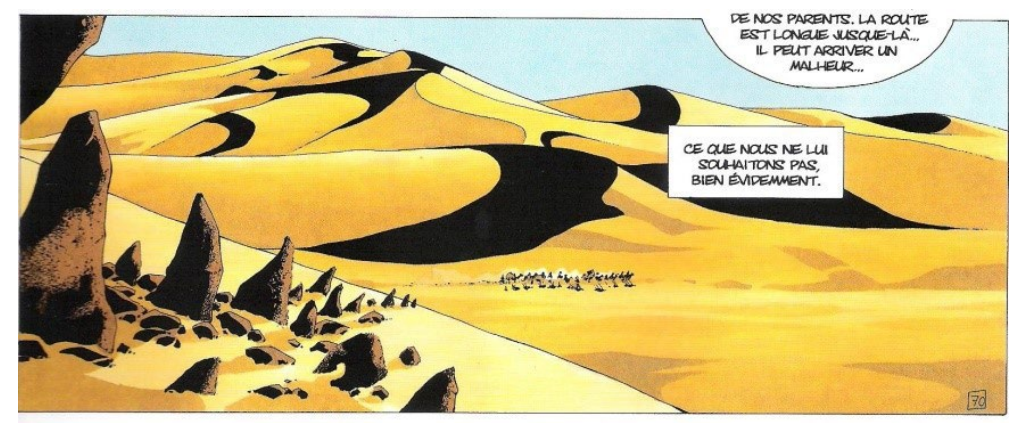

Croisade (vol. II: 22) Dufaux-Xavier, (c) Le Lombard

Bedouin tents house the horrible abductor Sarek Pacha and his harem. Orientalism is at its height with the lascivious Pacha luxuriating at the sight of his naked prisoner (vol. II: 30) or at his women, allowing the voyeuristic reader to penetrate into the tents. Seen in high-angle view, Syria sensuously lies on a 
bed, having been drugged with a magic potion allegedly allowing any sort of sexual fantasy (vol. II: 47).

The oriental house of the powerful djinn Ottar Benk lays hidden in a dilapidated village in the desert. The palace is the site of Orientalist fantasies containing stereotyped artefacts like the hall lavishly decorated with floral, gold geometric patterns in bright colours (gold, red and green), high wooden doors and Moorish arches. The enthroned monarch is wearing a red robe and glittering green jewels (vol. III: 41), bridging the gap between the exotic alien who gave birth to the monster AA and the archetypal wise old man who stands against any form of fanaticism (vol. IV: $18 ; 21 ; 23)$.

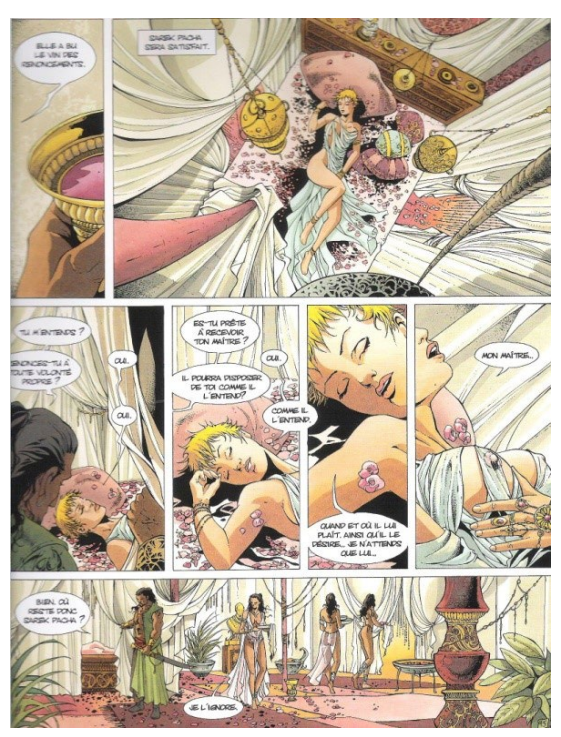

Croisade (vol. II: 47)

Dufaux-Xavier, @ Le Lombard

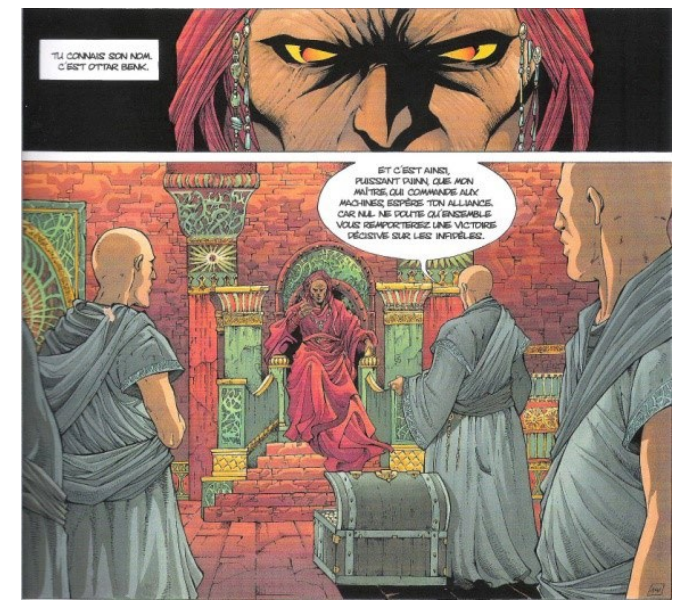

Croisade (vol. III: 41) Dufaux-Xavier, (C Le Lombard

\section{Architectural space}

Architecture has a poetic function that goes beyond de-familiarization from actual, real space to imaginary, unreal space: «to invent a particular building from one's own cultural reserves entails the invention of a culture that would make that building meaningfulı (Vesely, 2004: 29). Architectural drawings bring into being fantasies of spaces that are not simply «functional» — determined by a given function or a particular material, as they transform the field of creative possibilities, giving more depth to the adventure narrative. Rather, the «essential»» quality of space reconciles the form with the spiritual principle of the epoch, in a sort of nostalgic recreation of the past: «This illusion culminates in the belief that world is essentially each architect's own world. Everything created under such conditions is bound to be unique, and yet claims are often made for a universal validityı (Vesely, 2004: 28-29). 


\section{The Iconic City of HIERUS HALEM}

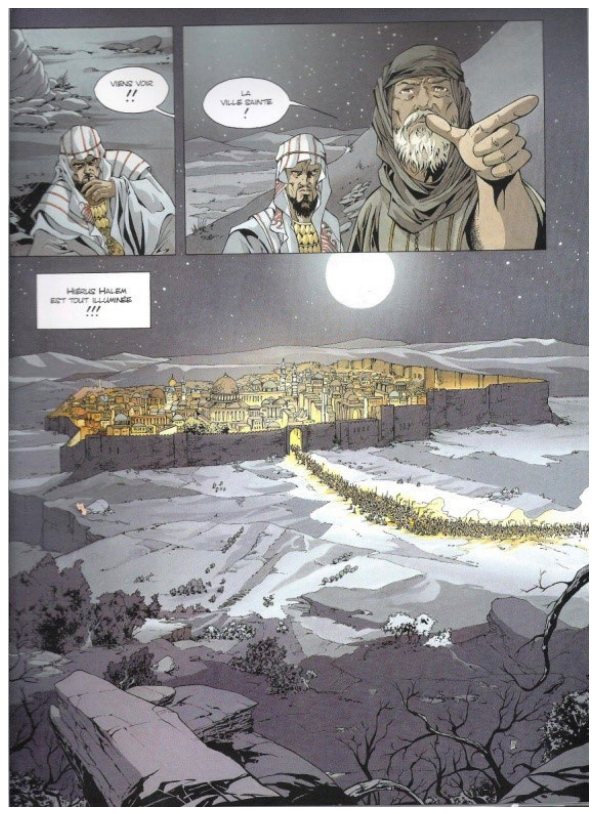
Dufaux-Xavier, @ Le Lombard

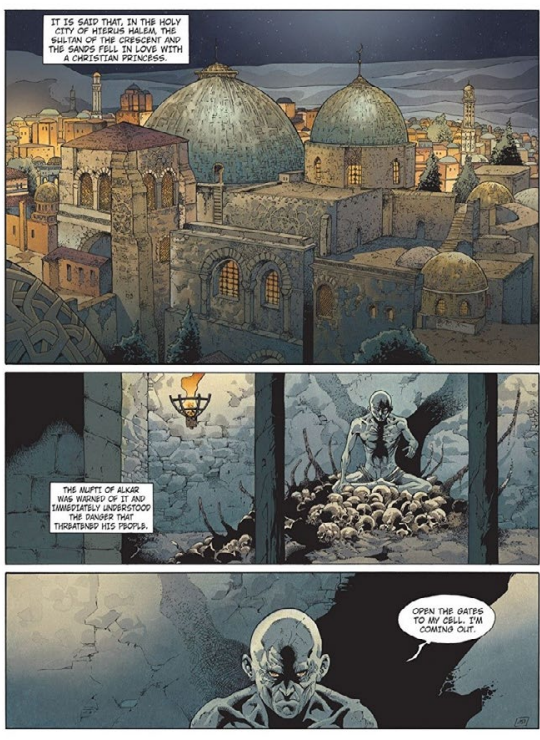

Croisade (vol. IV: 5 ) Dufaux-Xavier, ( Le Lombard
Croisade (vol. I: 15)

In Croisade the sacred city of Jerusalem often appears in panoramic views, as in a fullpage illustration at night with full moon and stars (vol. I: 15). As such, the city seems marvellously suffused with eerie light, as if pulsing with spiritual illumination from the hallowed procession of pilgrims. This decorative unit captures the reader's attention and triggers off a certain a-historical, iconic image of the town.

Its miscellaneous monuments and Holy Sites are detailed at night or in broad day light in warm, rose colours (vol. I: 30). One can recognize the $7^{\text {th }} \mathrm{c}$. Dome of the Rock, the Al-Aqsa mosque (built in 691) and the four minarets built between 1278-1367 (thus long after Saladin's 1187 conquest). Their juxtaposition appears as anachronistic recreation of Saladin's era, if one sticks to strict historicity. These vignettes are thus fantasized recreations escaping from temporality (vol. IV: 5).

The city glowing at night houses the idealized, magnanimous Sultan Ab'dul Razim, in the wake of the historical and legendary Saladin in both Arab and Western sources (Gorgievski, 2020). ${ }^{3}$ Ad'dul Razim revolts against the attack of a Christian caravan by his tribes and the abduction of Christian princess Syria (vol. II: 29). He exchanges Syria against some medicine to cure the plague-ridden abductor, in accordance with the legendary Saladin as medicine man (vol. II: 48-49).

The designers use overt referential illusion to evoke a medieval oriental town. The streets are detailed swarming with merchants, goods and tents (vol. I: 26) as well as miscellaneous animals (such as monkeys, dogs, reptiles and dromedaries), all of which suggests peace and plenty (vol. IV: 6). These details impart on space an objective coherence, purpose and meaning. 


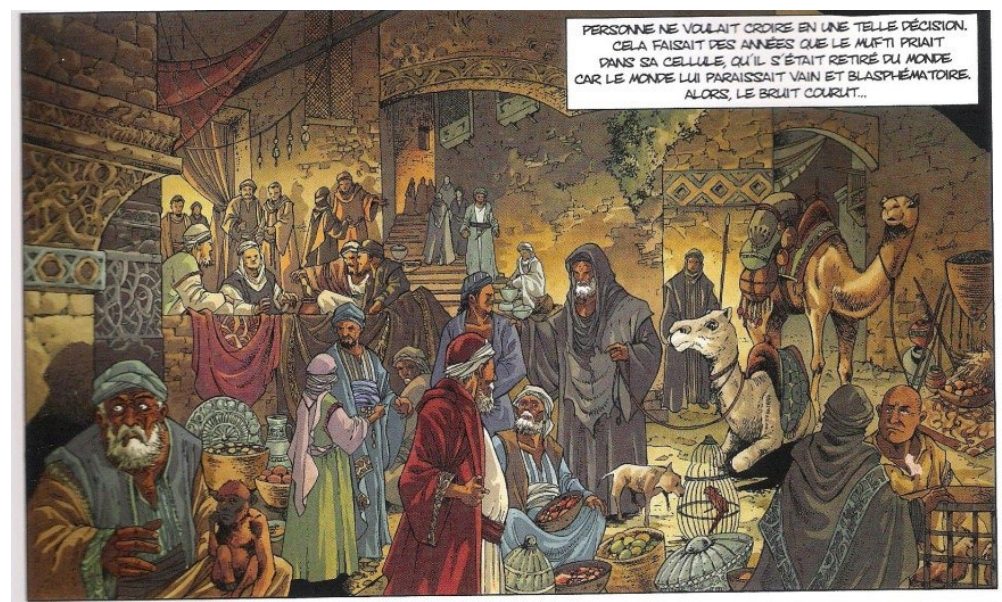

Croisade (vol. IV: 6) Dufaux-Xavier, (C) Le Lombard

A mosque is seen from inside, displaying the traditional Muslim architectural features: the mihrab - the shallow prayer niche indicating the direction of Mecca, and the minbar - the raised platform with its short staircase. Marble columns alternate with highly ornamented, semi-circular arches; a number of books, a reading desk, a Moorish table with a hookah (shisha) and a lamp constitute the space where the pious, dutiful sultan reads and prays (vol. I: 24).

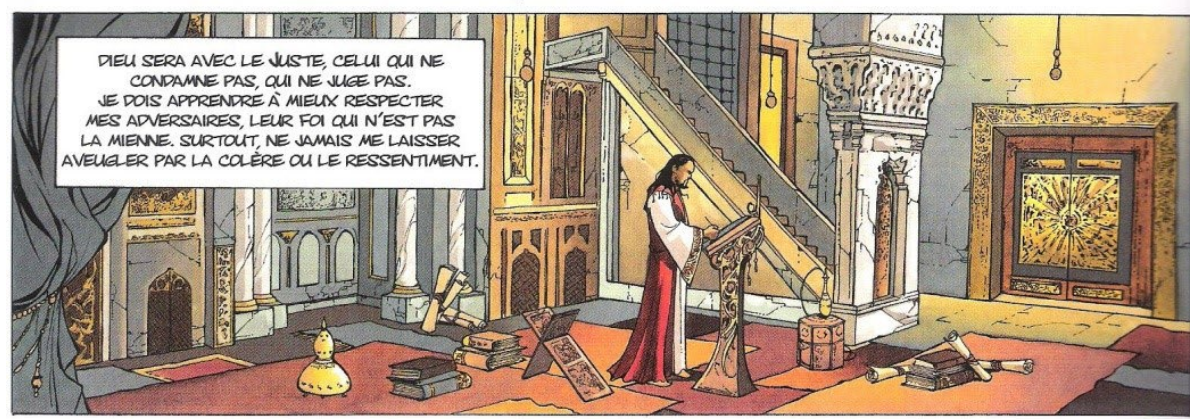

Croisade (vol. I: 24) Dufaux-Xavier, (c) Le Lombard

Yet the city of Jerusalem is also depicted as a site of religious feud and dispossession. A distant view reveals the town surrounded with an incandescently red desert, the gnarled burnt-out branches of a tree which figure slaughter against the Crusaders (IV: 48). A half-page places the Crusaders' war camp in the foreground with trebuchets and siege towers, while the city nestles in the background at sunset (vol. IV: 33). The siege is fully depicted in a fold-out, double page (vol. IV: 3438), later detailed in a full page, with raging fire and crumbling ramparts (vol. IV: 42).

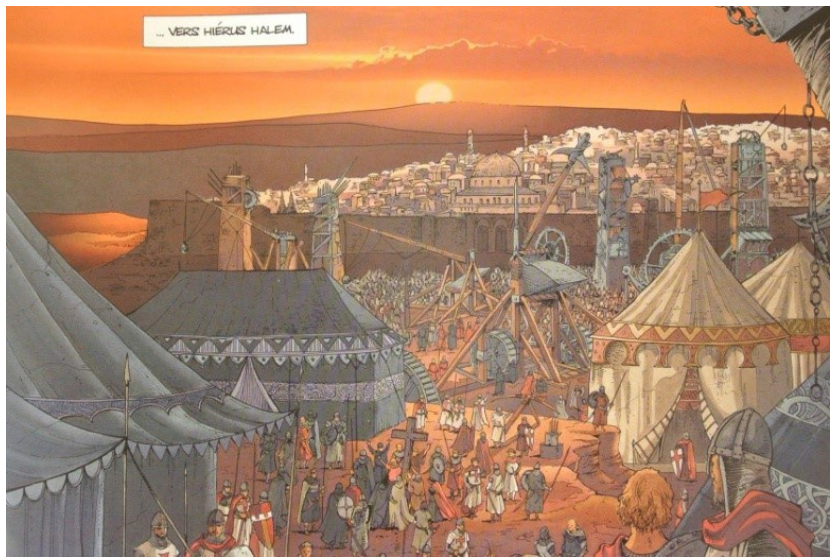

Croisade (vol. IV: 42)

Dufaux-Xavier, @ Le Lombard 


\section{Burial Sites}

The Holy Sepulchre containing the shrine of Christ is made into a daring architectural design. A half-page reveals an impressive interior, a decorated blue dome containing a black cuboid stone structure (vol. I: 52). It can be identified as a distorted version of the Kaaba, the open-air sanctified place of Islam in Mecca containing the sacred relic of a black stone. The resemblance is carefully handled, though. The entrance door is central -not lateral as in Mecca- and the outward walls are adorned with vertical - not horizontalgold panels bearing calligraphic motifs. As is visually suggested through architectural design, a striking cultural collision occurs with such a syncretic fusion of two architectural sacred spaces in the two monotheist religions. What's more, one can remember that during the pre-Islamic era, the Kaaba was a holy site for the various Bedouin tribes of the area.

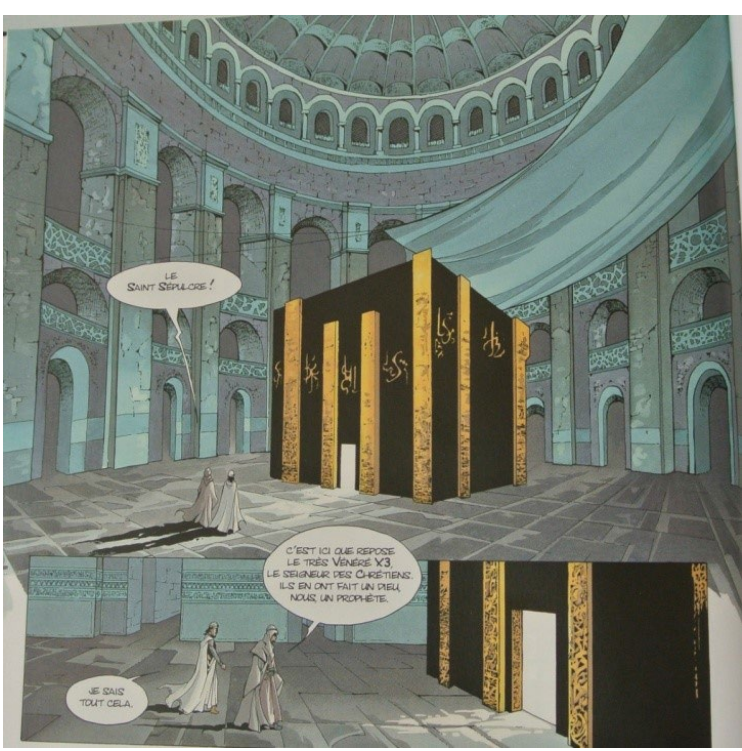

Croisade (vol. I: 52) Dufaux-Xavier, (C) Le Lombard

This imaginary sanctuary erases historical landmarks and indirectly confirms contemporary religious relativism in the Western world, in which sacred spaces are no longer intelligible to the largest part of the population. Indeed, following the second principle of heterotopias, burial sites can have a precise function or another according to the «synchrony» of the culture in which they occur, hence their displacement outside the city after the $19^{\text {th }} \mathrm{c}$. The belief in the resurrection of the body and the immortality of the soul was turned into an aesthetic cult, negating the possibility for belief.

Until the end of the eighteenth century, the cemetery was placed at the heart of the city, next to the church. In it there was a hierarchy of possible tombs. There was the charnel house in which bodies lost the last traces of individuality, there were few individual tombs and there were the tombs inside the church. These latter tombs were themselves of two types, either simply tombstones with an inscription, or mausoleums with statues. This cemetery housed inside the sacred space of the church has taken on a quite different cast in modern civilisation, and curiously, it is in a time when civilisation has become "atheistic» as one says very crudely, that western culture has established what is termed the cult of the dead (Foucault, 1984: 5-6).

In the final book, the sultan yields to the temptation of crushing the heart of Christ in the Holy Sepulchre in order to undermine any Crusader's wish to regain the shrine. This plot line corresponds to a daring version of the «traditionalist» historiography of the crusades which views them as a religious - rather than 
imperialistic - enterprise seeking to free Christians in the Near East and the Holy Sepulchre (Zouache, 2013: 142). Sultan Ad'dul Razim penetrates into the mausoleum - an event hardly imaginable in the Kaaba-only to find the body of the Light of the Martyrs instead. He refrains from killing her, thus disobeying the orders of his demonic counsellor Sar Mitra (vol. IV: 26-28).

Elsewhere in the series, other burial sites are gateways to nothingness. The subterranean temple where the Jews hide contains an antediluvian mammoth skeleton straight from prehistory (vol. II, p. 15). This striking image suggests a forward telescoping effect, a temporal displacement so that the reader perceives distant events as being more recent than they are. The catacombs also hide the monstrous beast of Apocalypse AA which feeds on the tribes of Jews.

Gauthier finds his father's tomb in a vaulted crypt containing Crusaders' tombs identified thanks to gigantic erect statues -rather than the recumbent gisants in medieval churches (vol. II: 52-53; vol. III: 14). He also finds his mother's tomb in a space adorned with Celtic patterns in

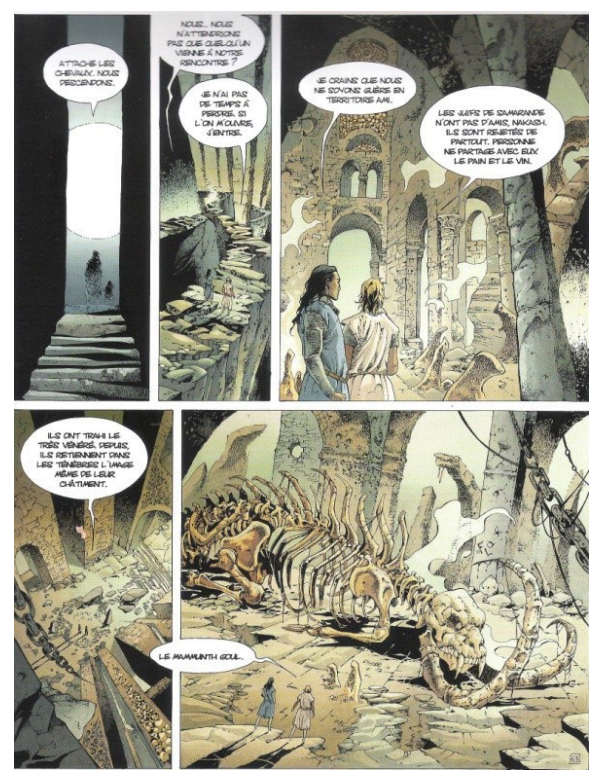

Croisade (vol. II: 15) Dufaux-Xavier, @ Le Lombard the midst of a sepulchral space with unearthed skeletons (vol. III: 34). Significantly, such an underworld voyage allows him to solve his mysterious heredity and to defeat the monster.

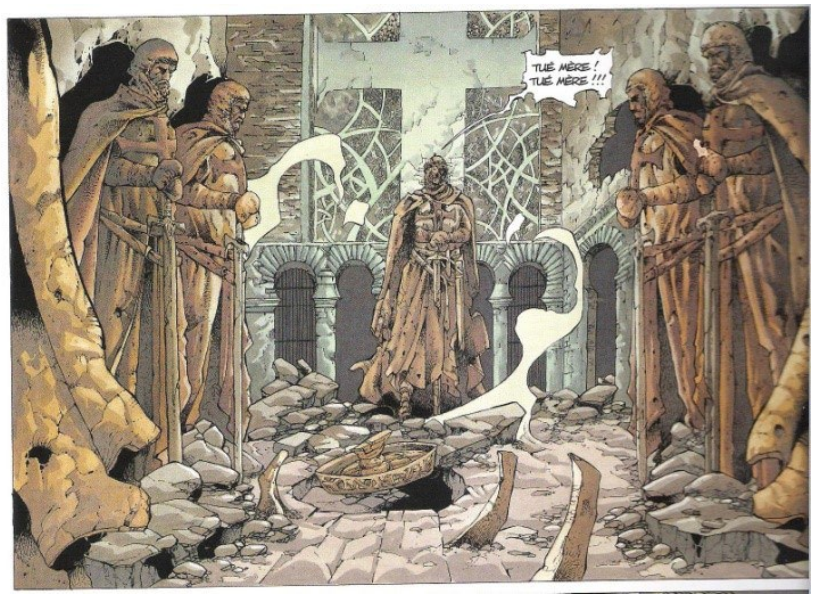

Croisade (vol. III: 14) Dufaux-Xavier, (C Le Lombard

The cryptic underworld of Jerusalem also contains prison-like ossuaries where a mysterious mufti, a sort of guru, enlightens the sultan (vol. I: 48); supernatural beings rise from the dead in typically gory scenes from heroic fantasy (vol. II: 14-15; vol. III: 7). 


\section{The Sultan's Garden}

Jerusalem holds spaces of domesticity, like the oriental palace housing the romance between the Christian princess Syria and the Muslim sultan, mirroring the legendary Saladin who allegedly seduced the Frankish queen in certain French romances, as in the $15^{\text {th }}$ C. anonymous Saladin (Régnier-Bohler, 1997: 465).

The sultan's apartments encapsulate the modern concept of privacy, with luscious bedrooms, canopied bed, couches with bouncy pillows, rugs, suspensions lights and richly adorned walls. All this furniture evokes sensuous encounter (vol. III: 16, 27, 31; vol. IV: 5). On the blue and turquoise ceramic tiled terrace, a pool recalls the oriental garden (vol. III: 17). Bi-coloured Moorish arches evoke an ancient Roman temple turned into a mosque as in Cordoba, suggesting the unity of the Islamic world (vol. III: 18).

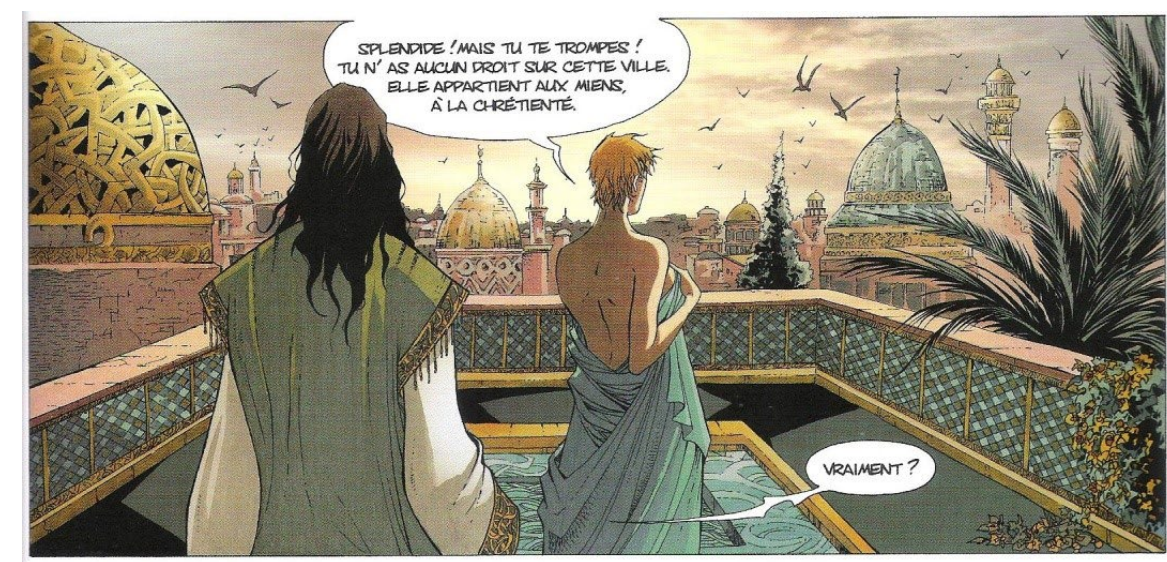

Croisade (vol. III: 17) Dufaux-Xavier, @ Le Lombard

The luxuriant garden is refreshed by a water basin with lily pads, trees, flower and a special banquet, providing the sultan with an intimate space to share secrets with the princess (vol. III: 32). According to Foucault, the garden is a contradictory site, a microcosm juxtaposed in a single location with other places, especially the oriental garden:

[the oriental garden] had very deep and seemingly superimposed meanings. The traditional garden of the Persians was a sacred place that was supposed to bring together inside its rectangle four parts representing the four parts of the world, with a space more sacred than the others that were like an umbilicus, the navel of the world at its centre (the basin and the water fountain were there). And all the vegetation of the garden was supposed to come together in this space (Foucault, 1984: 6) 


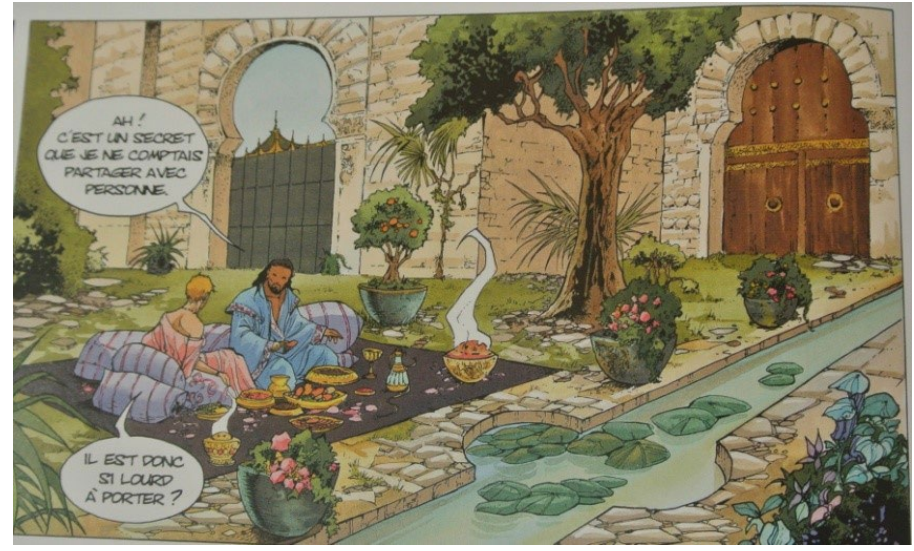

Croisade (vol. III: 32) Dufaux-Xavier, (C Le Lombard

When the mufti intrudes on the privacy of Ab'dul Razim's bedroom and of Syria's private apartment (vol. IV: 8) as well as on the harmonious, plentiful garden (vol. IV: 10-11), he symbolically endangers the fragile peace maintained by the Sultan. Indeed, although it is the smallest parcel of the world, the garden is also the totality of the world; it has been a happy, universalizing heterotopia since the beginnings of Antiquity (Foucault, 1984: 6)."

In the palace, the sultan's imposing study is another private place partaking of heterotopic space. Seen in high-angle view, it is full of books and furnished with rugs (vol. III: 18). Carpets were originally thought of as reproductions of gardens onto which the whole world comes to enact its symbolic perfection (Foucault, 1984: 7). The enclosed space of the library is yet another heterotopia evoking the Western modern idea of «a general archive encompassing all epochs, all forms of accumulated knowledge protected from the ravages of time») (Foucault, 1984: 7).

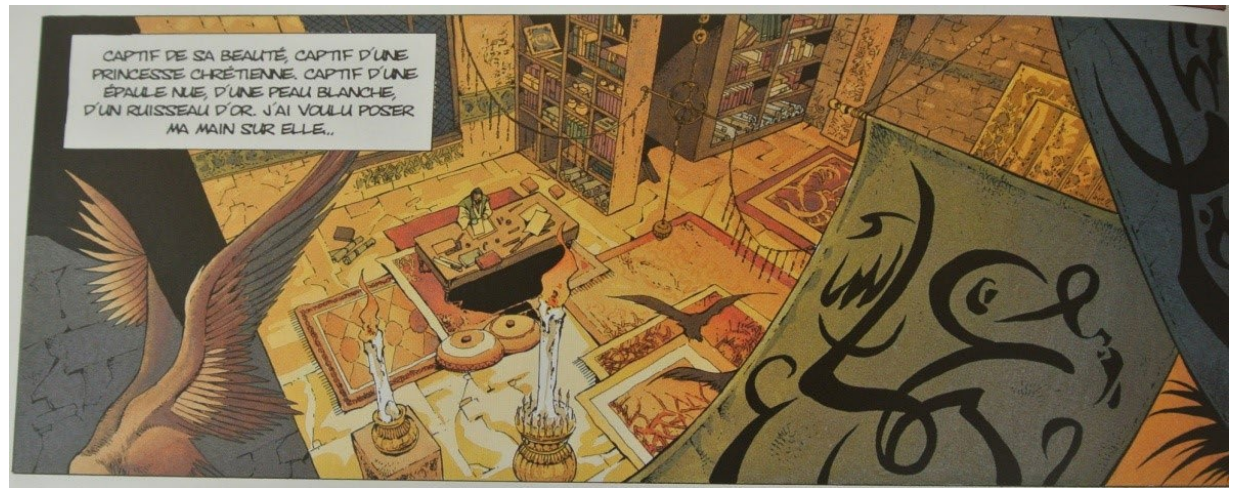

Croisade (vol. III: 18) Dufaux-Xavier, @ Le Lombard

\section{The Crusaders' Castle}

The site of the Christian defensive fortress in Croisade is reminiscent of the actual Crac des Chevaliers in Syria, a Crusaders' heritage and military architecture. Its 1933 acquisition and preservation by the French colonial state had major 
propagandist value as a reminder of the Frankish crusading presence in the East, which was glorified in order to legitimize the French expansion at the turn of the $20^{\text {th }} \mathrm{C}$. It was of prominent importance as French national heritage and was made popular through exhibitions to ushow the influence of French's art in foreign lands as a means to legitimize French presencel) (Swenson, 2015: 47, 53). Its cultural importance is still relevant today as a recent exhibition in Paris' Cité de l'Architecture et du Patrimoine has shown (Hofman \& Pénicault, 2018).

The stern, impressive fortress is silhovetted against a portentous black sky in the comics (vol. II: 22, 41). Other panels feature a full range of architectural details that have fed the picturesque vision of the military Crac des Chevaliers in the Levant: crenellated ramparts (vol. I: 42), a steep view over the desert and a dizzying talus (vol. II: 21, 33), a courtyard surrounded with a Gothic arcade gallery and ribbed vaults evoking the famous courtyard of the Crac (vol. III: 44).

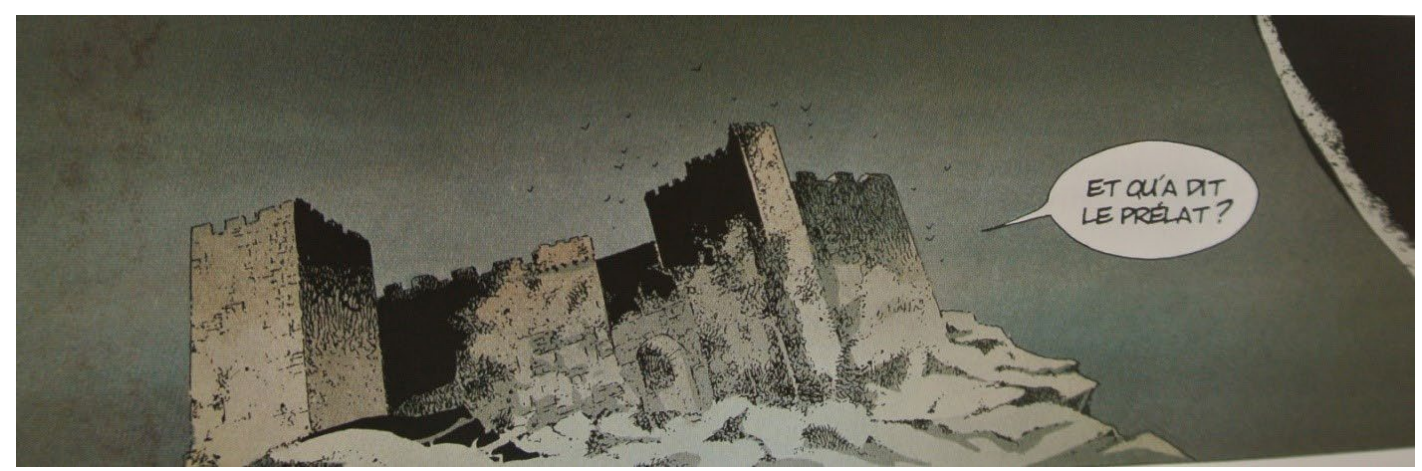

Croisade (vol. II: 22) Dufaux-Xavier, (C) Le Lombard

Inside, the fortress is designed in late Roman style with oriental influence, such as horseshoe arches (vol. I: 45) and a terrace (vol. I: 56). A chapel adorned with Byzantine frescoes (vol. II: 21). This type of syncretic design corresponds to what has been identified as the former part of the middle ground of the Roman Near East, for example the cities whose upolitical ambiguity was mirrored by the same level of equivocalnessi) (Sommer, 2012:241). In Palmyra, for example, Roman officials indulged in works of art which were iconographically and iconologically distinctly "Western»; but on the other hand, the temples and

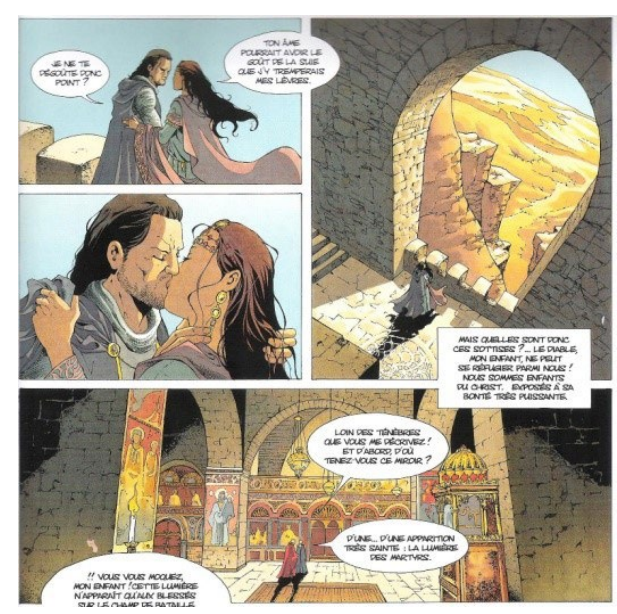

Croisade (vol. II: 21)

Dufaux-Xavier, (c) Le Lombard tombs which appeared 'classical' a first sight would in fact not been familiar to any Greek or Roman visitor.

The designers include elements that are part of historical record, but others as well: a regal balcony looks onto a porch, courtyard and side stairs, like the Romanesque Palace of the kings of Majorca in the French city of Perpignan. Some walls are decorated with Celtic knot patterns (vol. III: 19) or spiral motifs (vol. II: 40), an apartment is adorned with Renaissance-like frescoes (vol. IV: 12) and a Viking-like bedroom is furnished with bearskin carpet and large chest (vol. IV: 31). 
The fortress is also a symbolically enclosed place of ordeals in the wake of legendary, medieval remote castles. For example, Grégoire d'Arcos is tempted by the living dead in his canopy bed. The Primate of Venice is crushed by a high-angle view from Christ's cross, then gets morally lost in the perspective of arches when he discovers he was contaminated by the demon and later commits suicide from a steep tower (vol. II: 32). Significantly the two rivals the Duke of Taranto and the Master of the Machines joust in public in the solemn Gothic courtyard of the fortress for the right to conduct the Crusaders' army against the sultan (vol. III: 44).

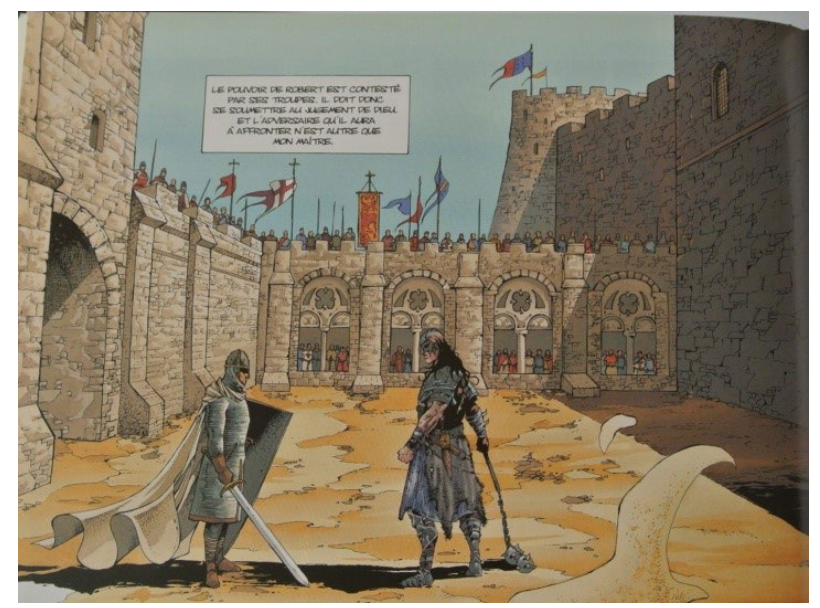

Croisade (vol. III: 44) Dufaux-Xavier, (C Le Lombard

Some objects furthermore testify to the importance of medieval science and technology. A map provides geographical lore (vol. III: 23), and a spherical astrolabe is sold by the aptly named Master of the Machines to the Christians at a very high price ( $v o l$. II: 40). The astrolabe was an armillary sphere known from Ancient Greece, then in the medieval Islamic world, before it was reintroduced to Western Europe via Al-Andalusia in the late $10^{\text {th }}$ century. ${ }^{4}$ In the series, it is on display in a hall decorated with Celtic spiral patterns that traditionally represent the brightest stars and planetary configurations.

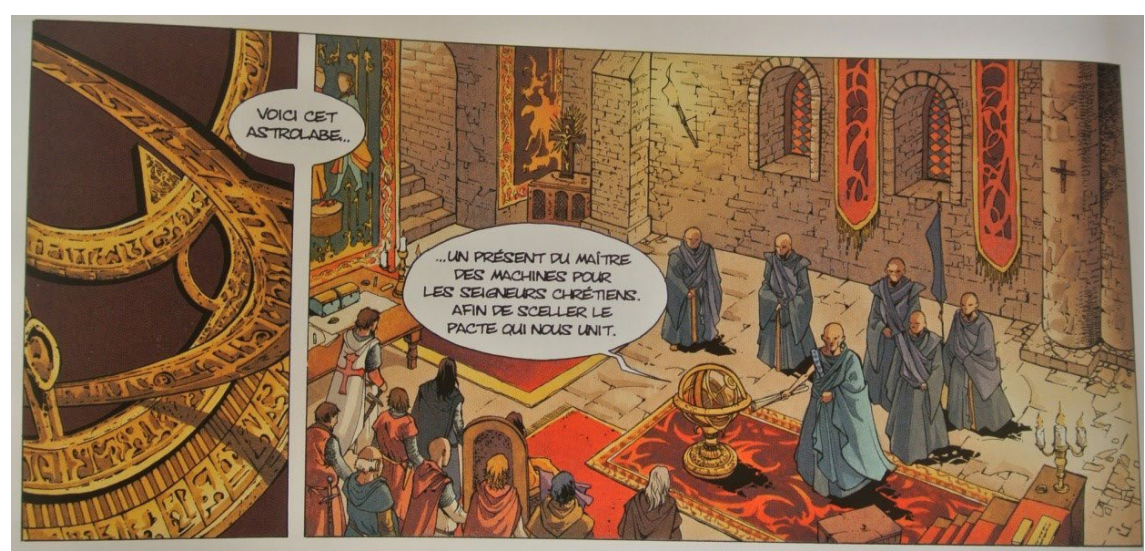

Croisade (vol. II: 40) Dufaux-Xavier, ( Le Lombard

4. As such, it differs from a celestial globe, which is a smooth sphere whose principal purpose is to map the constellations. It was invented separately in ancient Greece and ancient China. As illustrated in vol. II, it is a celestial sphere consisting of a spherical framework of rings, centered on Earth or the Sun, that represent lines of celestial longitude and latitude and other astronomically important features, such as the ecliptic. 
Crusaders also buy war machines, such as trebuchets and siege towers, to defeat the Muslims, in an indirect comment on warfare's "changing and increasingly impersonalized faces in the modern era (Knobler, 2006: 324). However, in spite of his technological superiority, the Master of the Machines fails to take Jerusalem. He is allowed to venture East in search of mysterious Red Lands containing Fire Beaks, where he discovers a new challenge.

The final panel of the series features a panoramic view on the desert, a scorched land filled with imaginary medieval technology, strange catapults telescoping medieval war implements with modern techniques of natural gas extraction (vol. IV: 50). Contemporary readers indeed immediately recognize oil well pump jacks.

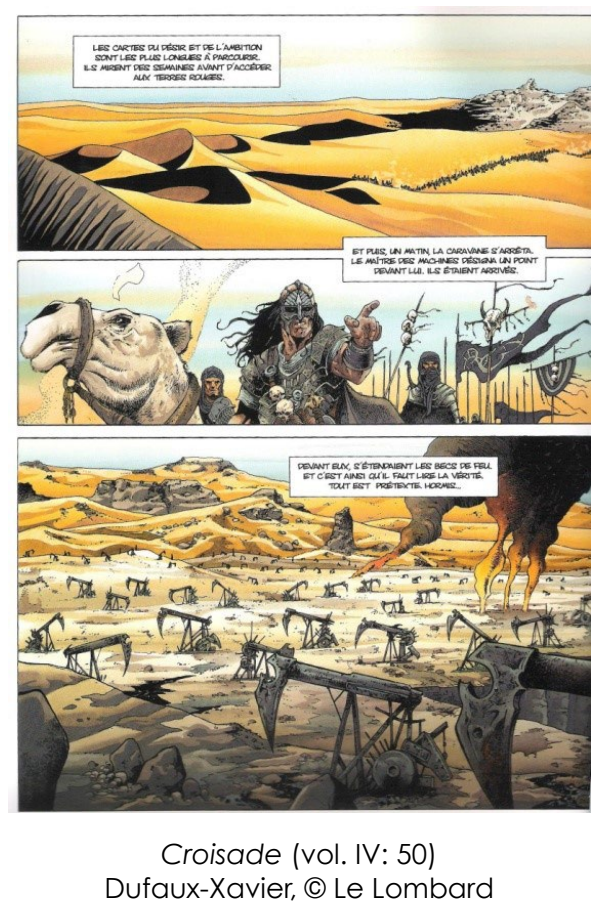

What's more, a final caption quotes medieval Arab traveller Ibn Jubayr, who recorded the presence of large oil seeps near Mosul in 1184 (Vassiliou, 2018: XXV). The series thus ends on the striking image of a technicized desert which bridges the gap between the medieval and the contemporary world.

To conclude, refashioning the crusades as an age of conflict and arbitrariness in plot, Jean Dufaux and Philippe Xavier juxtaposed varied ideological and religious discourses objectified in fantasized buildings and typologies of space - from ancient Roman, Celtic, Jewish, Christian to Muslim. Far from being a mere hybrid juxtaposition of diverse aesthetic tendencies, or a proselytizing comment on the crusades, the drawings reflect a "floating imagination" yet inscribed in our reality (Thévent \& Raubert, 2010: 96). Although what is at stake in a retelling of the crusades often conveys strong memorial perspectives, the interest of this series rather lies in the challenges of designing this period. The designs perfectly reflect our difficulties in recognizing any unicized view of the contemporary world, with all its historical layers and giddying access to other cultural patterns and ideologies. It is thus wavering between a traditional representation of the Middle Ages and a new, instrumental one in a «self-centered» culture. Creative design serves as mediation: «The primary purpose of representation, we may conclude, is its mediating role, which can also be described as participatory because it enhances our ability to participate in phenomenal reality) (Vesely, 2004: 18).

The authors of this series are granting access to a new level of reality where architectural and landscape designs are used as a visual language that seeks to emancipate itself from history and tradition, and to restore the original communicative context with the audience. Although personal and selfreferential, the series can be understood and shared by a whole community of readers. In an age when it is difficult to reconcile the abstract, conceptual 
representations of our world - from highly technicized, globalized representations to virtual reality, and the particular conditions and aspirations of our lives, this fascinating medievalist comics series offers not only a form of emancipation but also a sense of wholeness that helps transcend the fragmentary, discontinuous experience of today's world.

\section{Bibliografía}

Dufaux, Jean \& Philippe XaVIer (20092014), Croisade, Cycle I «Hierus Halemı, vol. I-IV, Bruxelles, Editions du Lombard.

Foucault, Michel, (1984), «Des espaces autres, Hétérotopiesı, Architecture, Mouvement, Continuité, 5, pp. 4649. English trans. by Jay Miskowiec (1986): «Of Other Spaces: Utopias and Heterotopiası, Diacritics 16(1), pp. 2227.

GORGIEVSKI, Sandra (2020), "Saladin, an Enduring Myth? Idealization from French Illuminated Manuscripts to Crusades Filmsı, in Othello's Island 2, Jane Chick and Michael Paraskos (eds.), London, The Orage Press.

KNOBLER, Adam (2006), "Holy Wars, Empires, and the Portability of the Past: The Modern Uses of Medieval Crusadesin, Comparative Studies in Society and History, 48(2), pp. 293325. DOI: https://doi.org/10.1017/ S0010417506000120

HOFMAN, Jean-Marc \& Emmanuel Pénicault (2018), Le Crac des Chevaliers, Chroniques d'un rêve de Pierre, Paris, Cité de l'architecture et du patrimoine. Le Goff, Jacques (1985), L'imaginaire médiéval, Paris, Gallimard.

Merleau-Ponty, Maurice

(1945), Phénoménologie de la perception. Paris, Gallimard.

Rapp, Claudia (2006), «Desert, City, and Countryside in the Early Christian
Imagination», Church History and Religious Culture, 86(1-4), pp. 93-112.

RéGNIER-Bohler, Danielle (ed.) (1997), Croisades et pèlerinages. Récits, chroniques et voyages en Terre Sainte, Xlle-XVle siècle, Paris, Robert Laffont.

SOMmer, Michael (2012), «Heart of Darkness? Post-colonial Theory and the Transformation of the Mediterraneanı, Ancient West and East, 11, pp. 235245. DOI: 10.2143/AWE.0.0.2175886.

SWEnson, Astrid, (2015), "Crusader Heritages and Imperial Presentation, Past and Present, 226, Supplement 10, pp. 27-56. DOI: 10.1093/pastj/gtu024

ThéVent, J. M. \& F. Raubert (2010), Architecture et bande dessinée: la ville dessinée, Paris, Cité de l'architecture et du patrimoine.

Vassiliou, Marius S. (2018), Historical Dictionary of the Petroleum Industry, $2^{\text {nd }}$ ed., Lanham, Rowman and Littlefield.

VESELY, Dalibor (2004), Architecture in the Age of Divided Representation. The Question of Creativity in the Shadow of Production, The MIT Press.

ZOUACHE, Abbès, (2013), «Écrire l'histoire des croisades, aujourd'hui, en Orient et en Occident», in Construire la Méditerranée, penser les transferts culturels. Approches historiographiques et perspectives de recherche, Rania Abdellatif, Yassir Benhima, Daniel König and Elisabeth Ruchaud (eds.), Munich, Oldenbourg, pp. 120-147. DOI : https://doi. org/10.1524/9783486989335.120 
GoRGIEVSKI, Sandra, «Re-framing the Crusades: The Representation of Space, Landscape and Architecture in the Comics Series Croisaden, Storyca 3 (2021), pp. 151-171. https://doi.org/10.51863/Storyca.2021.Gorgievski

\section{Abstract}

In both medieval and contemporary culture, defamiliarization in space frames the imagined relationship with the other in fantasized views of the East. This paper addresses ways the creative imagination functions in the contemporary four-volume Belgian comics series Croisade by Dufaux and Xavier (vol I-IV). They foster a self-reflexive vision of competing universes, from the Celtic to the ancient Roman, from the Moorish to the Gothic. The cultural relativism of our contemporary era seems more relevant than any attempt to historicize faithfully the fictional plot. These comic books exploit the visual evidence of space as emblematic natural sites of heterotopias like the desert, and architectural space like Jerusalem, some burial sites, the sultan's oriental palace and the Crusaders' fortress, while assessing the changing representation of space from the medieval era to the present.

\section{Resumen}

Tanto en la cultura medieval como en la contemporánea, la desfamiliarización del espacio enmarca la relación imaginada con el otro en visiones fantaseadas de Oriente. Este artículo aborda las formas en que funciona la imaginación creativa en la serie de cómics belga contemporánea Croisade, de Dufaux y Xavier, en cuatro volúmenes (vol. I-IV). En ellos, se fomenta una visión autorreflexiva de universos que compiten entre sí, desde el celta hasta el de la antigua Roma, desde el árabe hasta el gótico. El relativismo cultural de nuestra época contemporánea parece más pertinente que cualquier intento de historiar fielmente la trama de ficción. Estos cómics explotan la evidencia visual de los espacios como lugares naturales emblemáticos de heterotopías, como el desierto,

\section{KeyWords}

Crusades

Medieval Architecture

Comics

Syncretism

Heterotopia

Désert-forêt

\section{Palabras clave}

Cruzadas

Arquitectura medieval

Cómics

Sincretismo

Heterotopía

Desierto-bosque 
y el espacio arquitectónico, como Jerusalén, algunos lugares de enterramiento, el palacio oriental del sultán y la fortaleza de los cruzados, al tiempo que evalúan la representación cambiante del espacio desde la época medieval hasta el presente. 